\title{
Article \\ Circulating PTGS2, JAG1, GUCY2C and PGF mRNA in Peripheral Blood and Serum as Potential Biomarkers for Patients with Metastatic Colon Cancer
}

\author{
Cristina Jimenez-Luna ${ }^{1,2,3,+}$, Encarnación González-Flores ${ }^{3,4,+}$, Raul Ortiz ${ }^{1,2,3}$, Luis J. Martínez-González ${ }^{5}$ (D), \\ Alba Antúnez-Rodríguez ${ }^{5}$ D , Manuela Expósito-Ruiz ${ }^{6}$, Consolación Melguizo 1,2,3,*(D), Octavio Caba 1,2,3, ${ }^{\text {(D) }}$ \\ and Jose Prados $1,2,3, \ddagger$ (iD
}

1 Institute of Biopathology and Regenerative Medicine (IBIMER), Center of Biomedical Research (CIBM), University of Granada, 18100 Granada, Spain; crisjilu@ugr.es (C.J.-L.); roquesa@ugr.es (R.O.); ocaba@ugr.es (O.C.); jcprados@ugr.es (J.P.)

2 Department of Anatomy and Embryology, Faculty of Medicine, University of Granada, 18071 Granada, Spain 3 Instituto de Investigación Biosanitaria ibs. Granada, 18012 Granada, Spain; encarnagonzalezflores@gmail.com 4 Medical Oncology Service, Hospital Virgen de las Nieves, 18014 Granada, Spain

5 GENyO, Centre for Genomics and Oncological Research, Pfizer-University of Granada-Andalusian Regional Government, 18016 Granada, Spain; luisjavier.martinez@genyo.es (L.J.M.-G.); alba.antunez@genyo.es (A.A.-R.)

check for updates

Citation: Jimenez-Luna, C.; González-Flores, E.; Ortiz, R.; Martínez-González, L.J.; Antúnez-Rodríguez, A.; Expósito-Ruiz, M.; Melguizo, C.; Caba, O.; Prados, J. Circulating PTGS2, JAG1, GUCY2C and PGF mRNA in Peripheral Blood and Serum as Potential Biomarkers for Patients with Metastatic Colon Cancer. J. Clin. Med. 2021, 10, 2248. https://doi.org/10.3390/jcm10112248

Academic Editor: Hiroyuki Yoshida

Received: 16 April 2021

Accepted: 20 May 2021

Published: 22 May 2021

Publisher's Note: MDPI stays neutral with regard to jurisdictional claims in published maps and institutional affiliations.

Copyright: (c) 2021 by the authors. Licensee MDPI, Basel, Switzerland. This article is an open access article distributed under the terms and conditions of the Creative Commons Attribution (CC BY) license (https:/ / creativecommons.org/licenses/by/ $4.0 /)$.
6 Unit of Biostatistics, Department of Statistics and Operations Research, School of Medicine, University of Granada, 18071 Granada, Spain; mexpositoruiz@ugr.es

* Correspondence: melguizo@ugr.es; Tel.: +34-958-243535

+ These authors contributed equality.

$\ddagger$ These are Co-senior authors.

Abstract: Genes involved in the angiogenic process have been proposed for the diagnosis and therapeutic response of metastatic colorectal cancer (CRC). This study aimed to investigate the value of PTGS2, JAG1, GUCY2C and PGF-circulating RNA as biomarkers in metastatic CRC. Blood cells and serum mRNA from 59 patients with metastatic CRC and 47 healthy controls were analyzed by digital PCR. The area under the receiver operating characteristic curve (AUC) was used to estimate the diagnostic value of each mRNA alone or mRNA combinations. A significant upregulation of the JAG1, PTGS2 and GUCY2C genes in blood cells and serum samples from metastatic CRC patients was detected. Circulating mRNA levels in the serum of all genes were significantly more abundant than in blood. The highest discrimination ability between metastatic CRC patients and healthy donors was obtained with PTGS2 (AUC of 0.984) and GUCY2C (AUC of 0.896) in serum samples. Biomarker combinations did not improve the discriminatory capacity of biomarkers separately. Analyzed biomarkers showed no correlation with overall survival or progression-free survival, but GUCY2C and GUCY2C/PTGS2 expression in serum correlated significantly with the response to antiangiogenic agents. These findings demonstrate that assessment of genes involved in the angiogenic process may be a potential non-invasive diagnostic tool for metastatic CRC and its response to antiangiogenic therapy.

Keywords: metastatic colon cancer; biomarkers; angiogenesis; liquid biopsy; circulating mRNA; digital PCR

\section{Introduction}

Colorectal cancer $(\mathrm{CRC})$ is the second leading cause of cancer-related death worldwide with an incidence that is on track to increase from 1.8 million new cases in 2018 to 2.5 million in 2035. Despite numerous screening programs for early detection, approximately 20-25\% of patients exhibit metastatic disease at the disease onset and 50\% of patients eventually develop metastases [1-3]. The prognosis of metastatic CRC has improved in recent decades with the use of new treatment strategies, new biological agents and therapy optimization 
based on the genomic characteristics of the tumor. In fact, $R A S, B R A F$ and microsatellite instability (MSI) determination as well as some clinical biomarkers such as primary tumor location are essential to properly select patients who are candidates for biological treatments. In spite of these advances, the 5-year overall survival of these patients with advanced disease is still less than 15\% [4,5]. Currently, the European Society for Medical Oncology (ESMO) guidelines and the Pan-Asia adaptation recommend chemotherapy (CT) based on doublet cytotoxic combinations of fluorouracil, leucovorin and irinotecan (FOLFIRI) and 5-FU, leucovorin and oxaliplatin (FOLFOX) for metastatic CRC patients. Furthermore, targeted agents, such as EGFR antibody therapy in RAS will-type tumors and bevacizumab, are indicated in the first-line treatment of most patients [6-8]. In this context, the determination of a metastatic stage in CRC has become a priority in order to implement the most appropriate treatment that can improve the patient's prognosis.

Tissue biopsy biomarkers have been widely used to predict treatment response and prognosis of tumors. However, the invasiveness of the procedure and their low specificity has led to the use of peripheral blood to easily and non-invasively detect novel biomarkers with the potential to reflect tumor status [9-11]. Liquid biopsy has emerged as a promising tool for the follow-up of cancer patients [12]. In CRC, liquid biopsies showed promising clinical utility for early detection [13-15], relapse [16], prognostic markers [17], response to therapy [18] and survival [19]. Recently, long non-coding RNAs (lncRNAs) circulating in peripheral blood were proposed as a minimally invasive test for CRC diagnosis [20] and circulating tumor DNA (ctDNA)-based liquid biopsy for RAS mutations has also been used for some CRC diagnostic applications [21]. To this end, new biomarkers in blood directly related to cancer spread are of particular importance.

An essential phenomenon directly related to the development, proliferation and metastasis of CRC is angiogenesis, as demonstrated by four US Food and Drug Administrationapproved antiangiogenic agents for metastatic CRC (bevacizumab, ramucirumab, aflibercept and regorafenib) [22]. Among them, bevacizumab, a monoclonal antibody targeted against vascular endothelial growth factor (VEGF), has become a first-line treatment option in combination with chemotherapy for patients with metastatic CRC $[5,7,23]$, improving their response rate and survival [24,25]. Nevertheless, the high expectations raised by preclinical studies using antiangiogenic therapies were not fulfilled in clinical practice due to acquired or primary resistance [26-28]. A number of genes involved in the angiogenic process have been identified to be overexpressed in CRC progression and metastatization, and several non-invasive biomarkers have been proposed as potential biomarkers for predicting the prognosis and response to antiangiogenic therapy in this disease $[29,30]$. Biomarkers such as angiopoietin-2, soluble CD73, human epidermal growth factor receptor 3, hepatocyte growth factor, interleukin-6, stromal cell-derived factor 1 and vascular endothelial growth factor-D (VEGF-D) were tested in relation to antiangiogenic treatment. In fact, low VEGF-D expression has been found to improve bevacizumab response in CRC patients [31,32]. However, most of these studies require validation in larger patient cohorts to know who might benefit from these therapies [33].

Crosstalk between VEGF and other signaling pathways importantly contributes to tumor angiogenesis regulation, through the activation of alternative VEGF-dependent and VEGF-independent pathways [34]. Guanylyl cyclase C (GUCY2C), a receptor member of the family of guanyl cyclases, plays an important role in regulating intracellular cGMP levels, electrolyte homeostasis and cell proliferation in the intestine [35]. Deregulation of cGMP signaling observed in CRC involves the overexpression of GUCY2C and decreased levels of its ligands, resulting in hypofunction of the receptor, which could also contribute to loss of genomic integrity [36]. In last years, prostaglandin-endoperoxide synthase 2 (PTGS2) (also known as COX2), an inducible enzyme involved in the synthesis of prostaglandins that contributes to inflammation, angiogenesis, immune evasion and therapy resistance, has also been widely investigated in the tumor context [37]. Its overexpression has been associated with metastasis and poor prognosis in CRC patients [38]. On the other hand, the VEGF and Notch signaling pathways are two pivotal mechanisms in tumor angiogenesis [34]. In 
fact, placenta growth factor (PGF) is a ligand of the VEGF family that induces angiogenesis by both VEGF-independent and VEGF-dependent ways [39]. Interestingly, increased PGF levels in tumors resistant to anti-VEGF treatment suggest a possible compensatory role of PGF in angiogenesis induction [40]. In addition, Jagged-1 (JAG1) is a canonical ligand that activates Notch signaling that has been reported to be strongly upregulated in different cancers, including CRC, promoting tumor progression, angiogenesis and recurrence [41,42]. Finally, matrix metalloproteinase-7 (MMP7), a member of the zinc-dependent proteolytic enzymes family, degrades the extracellular matrix favoring tumor invasion, metastasis and angiogenesis by matrix-bound VEGF releasing [43]. Increased levels of this enzyme have been related with poor prognosis in advanced CRC [44].

The aim of this study was to assess the utility of five angiogenesis-related genes as biomarkers for predicting prognosis and response to different chemotherapy regimens combined with bevacizumab. Therefore, on the basis of the results previously reported in the literature and the potential clinical utility of using a panel of biomarkers in order to capture as much biological information as possible, we selected GUCY2C, JAG1, PTGS2, PGF and $M M P 7$ genes and determined circulating RNA levels in both peripheral blood mononuclear cells (PBMCs) and serum from patients with metastatic CRC using digital PCR (dPCR) technology. We demonstrated that PTGS2, GUCY2C and JAG1 in serum samples showed a high discrimination ability. Only JAG1 in blood showed a similar accuracy. Different clusters of biomarkers did not significantly improve this discriminatory capacity. However, GUCY2C and GUCY2C/PTGS2 in serum also correlated significantly with therapeutic response, although they did not correlate with overall survival or progression-free survival.

\section{Materials and Methods}

\subsection{Patients' Characteristics}

The clinical parameters of metastatic CRC patients who were finally included in the study after RNA extraction from blood and serum $(n=59)$ are summarized in Table 1. At the time of biomarker sampling, all patients had at least one radiologically visible metastasis. Of the 59 patients, $33(55.93 \%)$ were males and $26(44.07 \%)$ were females. The mean age was $60.12 \pm 11.16$ years. Two control groups were used for both blood $(n=28 ; 14(50 \%)$ males and $14(50 \%)$ females; mean age, $57.77 \pm 5.48$ years) and serum analyses $(n=19 ; 14(73.68 \%)$ males and $5(26.32 \%)$ females; mean age, $65.50 \pm 6.83$ years). The RAS gene was shown to be mutated in $31(52.54 \%)$ patients and $35(59.32 \%)$ patients presented metastasis in more than 1 organ. Regarding therapy, $35(59.32 \%)$ patients received chemotherapy involving antiangiogenic treatment while $24(40.68 \%)$ were not administered any antiangiogenic drug.

\subsection{Biomarker Correlation with Overall Survival or Progression-Free Survival}

A total of 66 patients with CRC were initially recruited and whole blood samples were collected before receiving any anticancer treatment (chemotherapy $+/-$ targeted agents) at the Medical Oncology Service of the Virgen de las Nieves University Hospital (Granada, Spain). All patients were confirmed as metastatic CRC (stage IV). The diagnosis of CRC, which was histologically confirmed by surgery or biopsy and metastatic CRC, was based on imaging studies. In addition, samples from 47 age- and sex-matched healthy controls were selected so that none of them presented any type of tumor or inflammatory pathology and were then obtained from the Andalusian Health System Biobank (Granada, Spain). Assessment of therapeutic response was based on responders/non-responders. The study was approved by the Biomedical Research Ethics Committee of the Andalusian Public Health System in Granada (protocol code PI19/01478; No. 2020522131049; 29 July 2020 ) and conducted in accordance with the Declaration of Helsinki, and written informed consent was obtained from all participants. 
Table 1. Characteristics of metastatic CRC patients.

\begin{tabular}{|c|c|}
\hline Characteristic & CRC Patients \\
\hline Age (years $\pm \mathrm{SD}$ ) & $60.12 \pm 11.16$ \\
\hline \multicolumn{2}{|l|}{ Sex } \\
\hline Male & 33 \\
\hline Female & 26 \\
\hline \multicolumn{2}{|l|}{ RAS gene } \\
\hline Non-mutated & 28 \\
\hline Mutated & 31 \\
\hline \multicolumn{2}{|l|}{ Metastasis } \\
\hline One organ & 24 \\
\hline More than one organ & 35 \\
\hline \multicolumn{2}{|l|}{ Therapy } \\
\hline $\begin{array}{c}\text { Chemotherapy + } \\
\text { antiagiogenic }\end{array}$ & 35 \\
\hline Chemotherapy & 24 \\
\hline \multicolumn{2}{|l|}{ Tumor location } \\
\hline Rectum & 21 \\
\hline Transverse/Left colon & 27 \\
\hline Right colon & 11 \\
\hline \multicolumn{2}{|l|}{ Metastatic site } \\
\hline Liver & 36 \\
\hline Lung & 9 \\
\hline Peritoneum & 7 \\
\hline Lymph nodes & 5 \\
\hline Other & 2 \\
\hline \multicolumn{2}{|l|}{ Treatment } \\
\hline Antiangiogenic treatment & 35 \\
\hline No antiangiogenic treatment & 24 \\
\hline
\end{tabular}

\subsection{RNA Isolation from Blood Cells and Serum Samples}

To extract RNA from blood cells, whole blood samples $(6 \mathrm{~mL})$ from each patient were collected into Tempus Blood RNA tubes (Thermo Fisher Scientific, Waltham, MA, USA; CAT: 4342792) and vigorously mixed for at least $10 \mathrm{~s}$ after collection. Samples were incubated at room temperature for $24 \mathrm{~h}$ and then total RNA from the lysed blood cells was isolated using the Tempus Spin RNA Isolation Reagent Kit (Thermo Fisher Scientific, Waltham, MA, USA; REF: 4378926) following the protocol provided by the manufacturer.

In addition, to obtain serum-circulating RNA, matched peripheral blood samples $(8.5 \mathrm{~mL})$ from each patient were collected in BD Vacutainer SSTII advance tubes (Becton Dickinson, Franklin Lakes, NJ, USA) and were allowed to clot for at least $30 \mathrm{~min}$. The serum fraction was obtained by centrifugation at $1400 \times g$ for $10 \mathrm{~min}$ and then stored at $-80{ }^{\circ} \mathrm{C}$ until processing. For total RNA isolation, $300 \mu \mathrm{L}$ of serum was concentrated to $200 \mu \mathrm{L}$ using a vacuum concentrator (Vacufuge plus Vacuum Concentrator, Eppendorf AG, Hamburg, Germany) at $4{ }^{\circ} \mathrm{C}$. Circulating free total RNA was purified with the miRNeasy Serum/Plasma Kit (Qiagen) according to the manufacturer's instructions. Whole blood and serum samples from healthy controls were collected and processed identically to those from CRC patients. The concentration and quality of purified RNA were assayed using a NanoDrop 2000c spectrophotometer (Thermo Fisher Scientific) and a 2100 Bioanalyzer instrument (Agilent Technologies, Santa Clara, CA, USA), respectively. Only samples with RIN $\geq 9$ were used for subsequent experiments.

\subsection{Digital PCR}

Colorectal cancer patients with both matched blood and serum samples available that had passed quality control were included in the gene expression analysis. Total RNA 
(150 ng) from blood cells and serum was reverse transcribed in $20 \mu \mathrm{L}$ reaction volume using a SuperScript ${ }^{\mathrm{TM}}$ VILO $^{\mathrm{TM}}$ cDNA Synthesis Kit (Thermo Fisher Scientific) according to the manufacturer's manual. Digital PCR was performed with the QuantStudio ${ }^{\text {TM }}$ 3D Digital PCR System (Life Technologies, Carlsbad, CA, USA) according to the manufacturer's recommendations. Reactions were performed in a final volume of $18 \mu \mathrm{L}$ containing Quantstudio 3D Digital Master Mix v2 $(9 \mu \mathrm{L})$, TaqMan assay-FAM $(0.6 \mu \mathrm{L})$, TaqMan assay-VIC $(0.6 \mu \mathrm{L})$, nuclease-free water $(2.8 \mu \mathrm{L})$ and $7.5 \mathrm{ng}$ of template cDNA $(5 \mu \mathrm{L})$. Samples $(16 \mu \mathrm{L})$ were loaded onto chips using the QuantStudio 3D Digital Chip Loader (Life Technologies, Carlsbad, CA, USA) and cycled according to the following parameters: $96^{\circ} \mathrm{C}$ for $10 \mathrm{~min}$, followed by 20 cycles at $59{ }^{\circ} \mathrm{C}$ for $2 \mathrm{~min}$ and $98^{\circ} \mathrm{C}$ for $30 \mathrm{~s}, 25$ cycles at $57^{\circ} \mathrm{C}$ for $2 \mathrm{~min}$ and $98^{\circ} \mathrm{C}$ for $30 \mathrm{~s}$ and a final elongation step at $57^{\circ} \mathrm{C}$ for $7 \mathrm{~min}$ and then $10^{\circ} \mathrm{C}$ hold. All samples were run in duplicate. The TaqMan probes (Life Technologies, Carlsbad, CA, USA) used for target gene detection were GUCY2C (Hs00990120_m1), MMP7 (Hs01042796_m1), JAG1 (Hs01070032_m1), PGF (Hs00182176_m1) and PTGS2 (Hs00153133_m1). The MTR gene (Hs01090026_m1), whose expression was stably shown by qPCR, was selected among five commonly used endogenous genes and employed as housekeeping for expression normalization. After thermo-cycling, the QuantStudio ${ }^{\mathrm{TM}}$ 3D Digital PCR Instrument (Life Technologies, Carlsbad, CA, USA) and the QuantStudio ${ }^{\mathrm{TM}}$ 3D AnalysisSuite ${ }^{\mathrm{TM}}$ Software (Life Technologies, Carlsbad, CA, USA) were used to collect and analyze the end-point fluorescence data of each chip according to the manufacturer's instructions. The absolute concentration of the target gene per $\mu \mathrm{L}$ of input DNA (copies $/ \mu \mathrm{L}$ ) was obtained and then normalized using the MTR expression. Finally, the $\Delta \mathrm{Ct}$ was calculated for each sample $(\Delta \mathrm{Ct}=$ no. FAM/no. VIC).

\subsection{Statistical Analyses}

Gene expression levels between the two groups were compared using unpaired Student's t-tests (Welch's correction was applied for data groups with unequal variances) or the Mann-Whitney or Wilcoxon matched-pairs tests, as appropriate. Outliers were identified by applying the ROUT test. To establish the cut-off point with the best predictive capacity for each biomarker as well as their combination, the Youden's index was calculated from the sensitivity and specificity values of each of the coordinates obtained in the ROC curve. Once the cut-off point for each biomarker was established, sensitivity, specificity, positive predictive values (PPV) and negative predictive values (NPV) were calculated, as well as the area under the ROC curve (AUC). A significance level of 0.05 was considered for hypothesis testing. In addition, the relationship between each biomarker and the response to treatment was analyzed using Pearson's chi-squared test or, in cases in which the applicability conditions were not met, Fisher's exact test. Survival curves were estimated with the Kaplan-Meier method (95\% confidence intervals (CIs)), and the differences between subgroups were compared using the log-rank test. Data were analyzed with IBM SPSS Statistics 19 software and GraphPad Prism 7 (GraphPad Software, San Diego, CA, USA).

\section{Results}

\subsection{Differential Gene Expression in Metastatic CRC Patients}

In total, 59 CRC blood samples were analyzed for gene expression by dPCR. Three of the five candidate angiogenesis-associated biomarkers demonstrated statistically significant differences in expression between CRC patients and healthy controls in the blood samples (Figure 1). A significant upregulation of JAG1 $(p<0.0001)$, PTGS2 $(p<0.0001)$ and GUCY2C $(p=0.0349)$ genes was observed in blood cells from CRC patients compared to controls (Figure 1A-C). In contrast, MMP7 and PGF presented similar expression levels between both study groups (Figure 1D,E). 

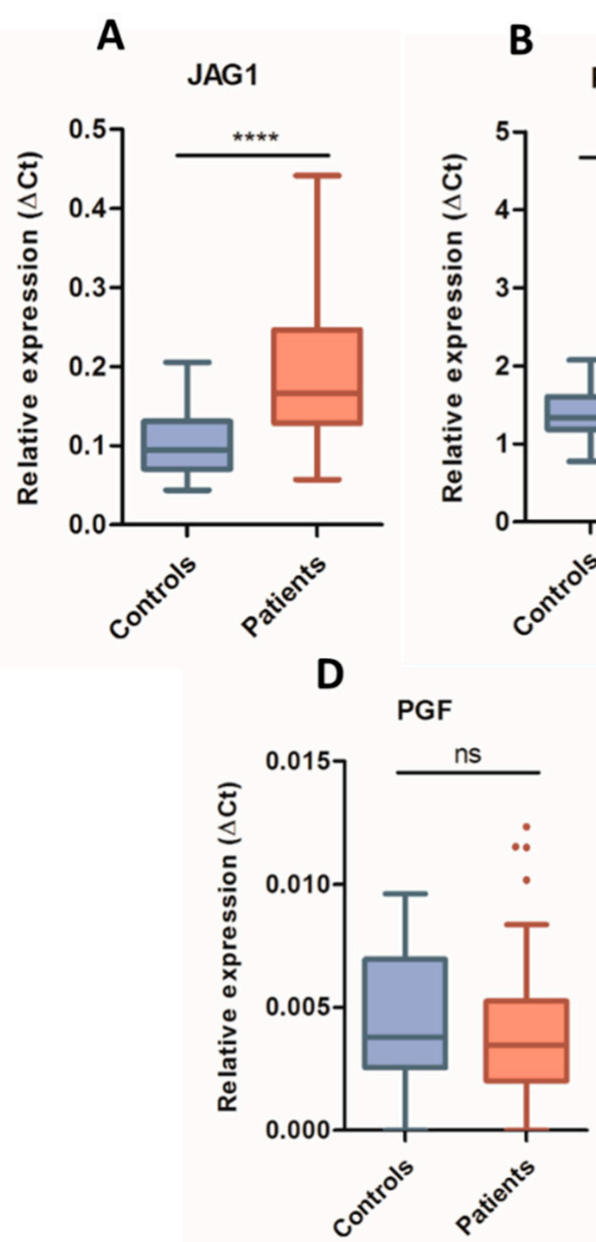

B

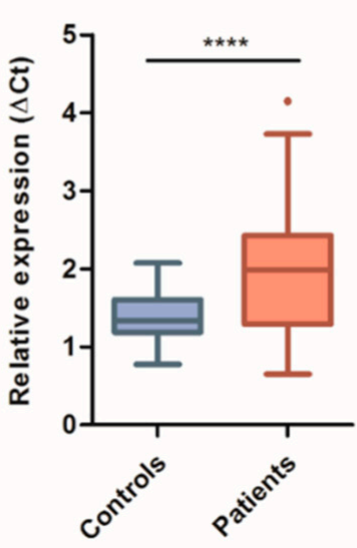

C GUCY2C

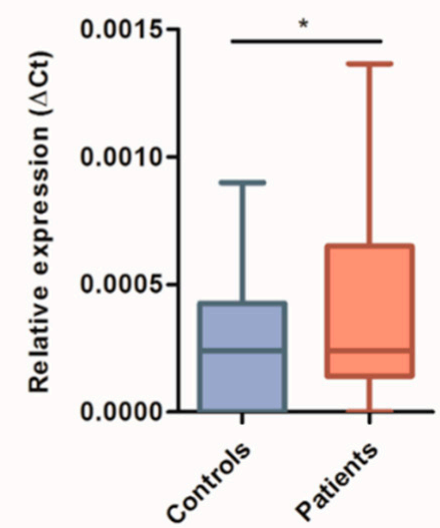

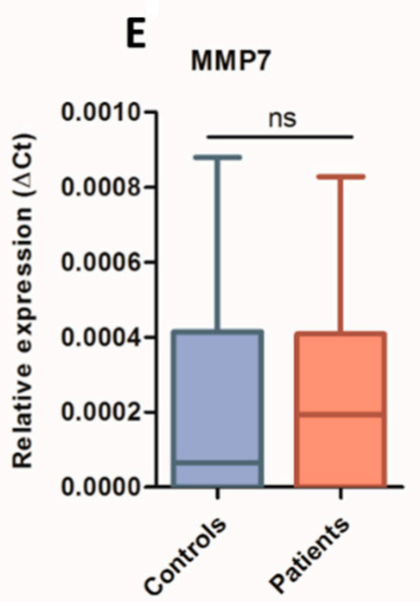

Figure 1. Relative quantification of gene expression levels by digital PCR in whole blood samples. Expression levels of JAG1 (A), PTGS2 (B), GUCY2C (C), PGF (D) and MMP7 (E) genes were determined in whole blood samples from metastatic colon cancer patients (red) and healthy controls (blue), normalized by MTR expression and calculated by the $\triangle \mathrm{Ct}$ method. In box plots, boxes show the interquartile range (IQR), whiskers indicate Q1-1.5xIQR and Q3 + 1.5xIQR values, inner lines indicate medians. $\left({ }^{*}\right) p<0.05 ;(* * * *) p<0.0001$; (ns) not significant.

Next, we selected the most upregulated genes (JAG1, PTGS2 and GUCY2C) in the blood cells of CRC patients to determine the presence of circulating mRNA in the matched serum samples. As shown in Figure 2, the three modulated genes showed a clear and statistically significant $(p<0.0001)$ upregulation in serum from these patients (Figure 2A-C) relative to controls. Furthermore, although PGF was not significantly increased in blood cells from CRC patients, it was also analyzed because of its role promoting angiogenesis, in resistance to antiangiogenic therapy and as an alternative pro-angiogenic ligand to VEGF-A in the VEGF pathway. PGF showed a clear upregulation $(p<0.01)$ in our cohort of patients (Figure 2D). 
A

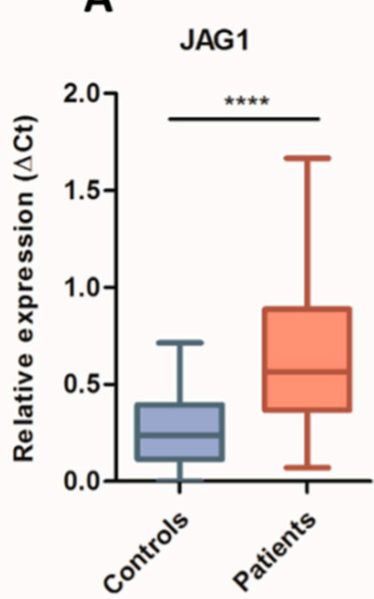

C GUCY2C

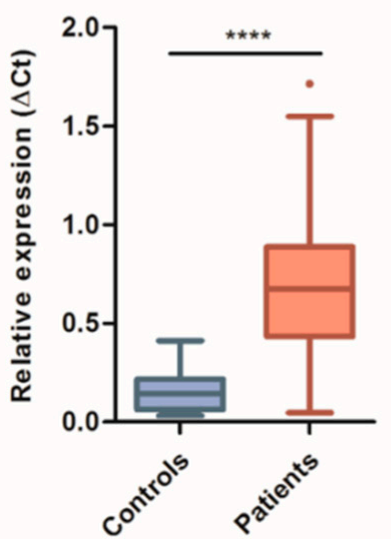

B

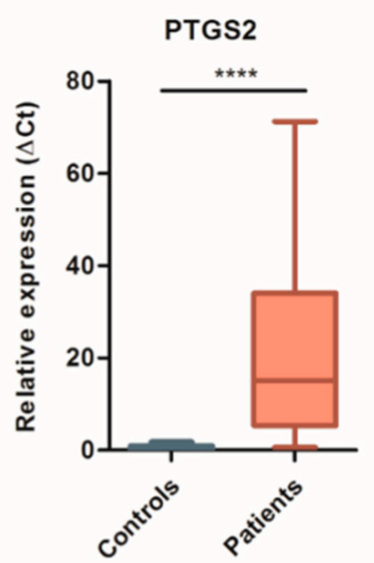

D

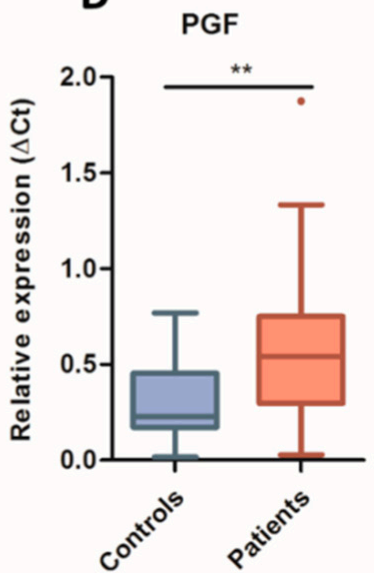

Figure 2. Relative quantification of gene expression levels by digital PCR in serum samples. Expression levels of JAG1 (A), PTGS2 (B), GUCY2C (C) and PGF (D) genes were determined in serum from metastatic colon cancer patients (red) and healthy controls (blue), normalized by MTR expression and calculated by the $\Delta \mathrm{Ct}$ method. In box plots, boxes show the interquartile range (IQR), whiskers indicate Q1-1.5xIQR and Q3 + 1.5xIQR values, inner lines indicate medians. $\left.{ }^{* *}\right) p<0.01 ;\left({ }^{* * * *}\right) p<0.0001$; (ns) not significant.

\subsection{Different $m R N A$ Levels in Serum and Whole Blood Samples}

To analyze the differences regarding the mRNA levels present in both types of samples, the expression of each individual gene obtained by $\mathrm{dPCR}$ in both fluids was compared in the CRC patient group. Our results showed that circulating mRNA levels in the serum of all genes were significantly more abundant than in blood cells $(p<0.0001$; Figure 3$)$, with GUCY2C and PGF being especially low in the whole blood compared with serum samples (Figure 3C,D). This result reveals that serum is a reliable source of circulating mRNA-based biomarkers. 
A

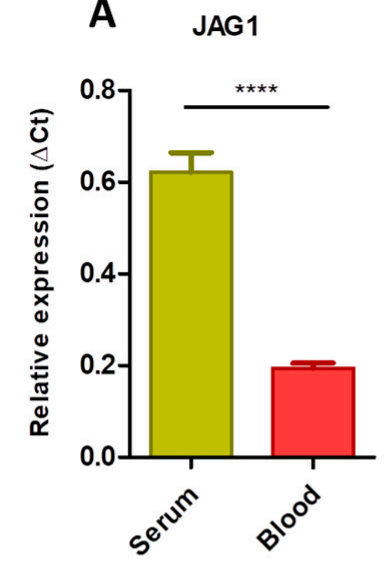

C

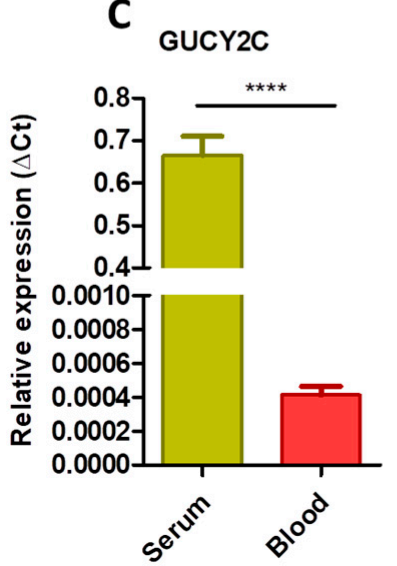

B PTGS2

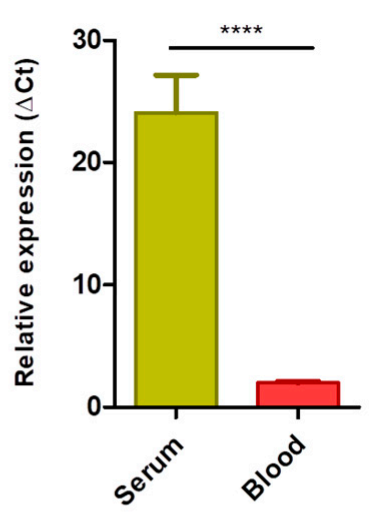

D PGF

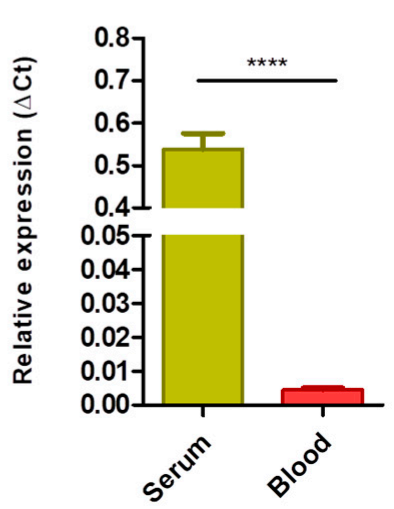

Figure 3. Comparison of gene expression levels obtained by digital PCR in matched serum and blood cell samples from patients with metastatic colon cancer. Expression levels of JAG1 (A), PTGS2 (B), GUCY2C (C) and PGF (D) genes were normalized by MTR expression and calculated by the $\Delta \mathrm{Ct}$ method (data represent mean \pm SEM). $\left.{ }^{* * * *}\right) p<0.0001$.

\subsection{Correlation Analysis of Candidate Biomarkers}

Analysis of the possible correlation between the selected biomarkers, which are related to angiogenesis events, showed a low correlation coefficient. Specifically, JAG1, GUCY2C and PTGS2 mRNA levels in serum showed irrelevant or modest correlations with each other $(\mathrm{r}=0.26-0.42 ; p<0.05)$. On the other hand, only a moderate correlation between JAG1 and GUCY2C expression in blood cells was detected $(\mathrm{r}=0.55 ; p<0.0001)$. Additionally, we evaluated possible associations for each individual biomarker in serum and blood cells, but no significant correlations were found in our study population suggesting that whole blood and serum can be considered as independent measurement sources.

\subsection{Sensitivity and Specificity as Biomarker Signatures in Blood and Serum}

Given the high expression of JAG1, GUCY2C, PTGS2 and PGF genes in CRC, we performed a ROC curve analysis and calculated the AUC to investigate their individual ability to discriminate between CRC patients and healthy subjects. We also combined these genes in different panels to examine their potential diagnostic advantages. Overall, the blood-derived results showed that $J A G 1$ was the biomarker with the best performance, with an AUC value of 0.858 ( $95 \%$ CI, 0.778-0.937) (Figure 4). Analysis of the other genes did not show a great discriminatory capacity (AUC $<0.80$ ). Moreover, the different combinations of the genes analyzed in blood did not provide additional benefits. 


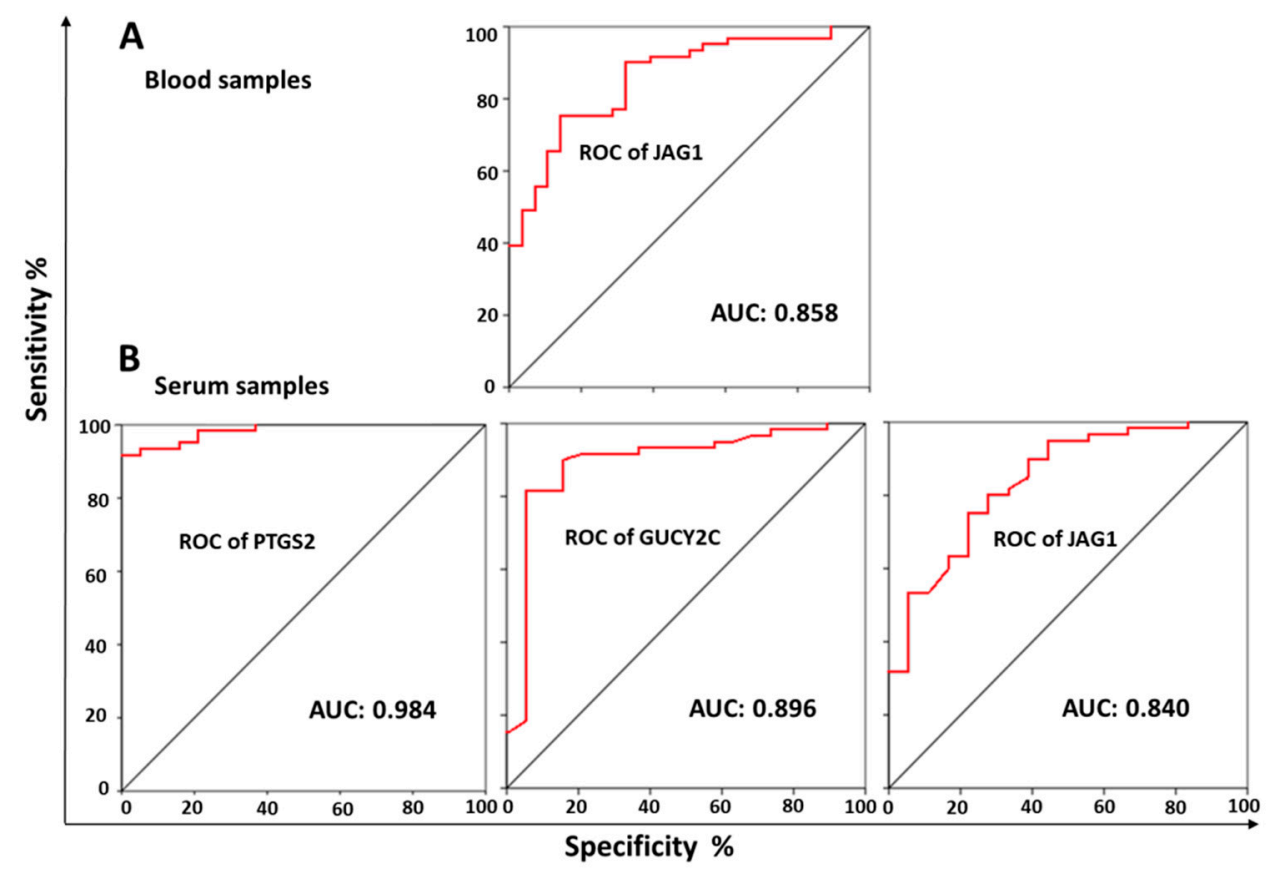

Figure 4. Receiver operating characteristic (ROC) curves analysis. The area under the ROC curve (AUC) with 95\% of confidence intervals (CIs) was obtained to evaluate the diagnostic accuracy of individual blood-derived circulating mRNAs of JAG1 (A) and individual serum-derived circulating mRNAs of PTGS2, GUCY2C and JAG1 (B).

Remarkably, ROC analyses of circulating mRNA in serum showed higher AUC values than in blood cells for almost all individual biomarkers, most notably PTGS2 with an AUC of 0.984 (95\% CI, 0.963-1.000) and GUCY2C with an AUC of 0.896 (95\% CI, 0.803-0.988). In this type of sample, JAG1 showed a similar performance to that found in blood (AUC of $0.840,95 \%$ CI, $0.737-0.943)$.

Regarding serum pairs, the JAG1-GUCY2C and JAG1-PTGS2 combinations showed an AUC of 0.819 (0.728-0.910) and 0.831 (0.743-0.743), respectively, which did not improve the discriminatory ability of JAG1 alone. Similarly, the combination of the PTGS2 gene with others such as GUCY2C and PFG (PTGS2-GUCY2C and PTGS2-PFG) showed an AUC value of $0.879(0.805-0.953)$ and $0.852(0.772-0.933)$, respectively; thus, this association did not improve the discriminatory ability of the individual biomarkers. Finally, only the use of three biomarkers (GUCY2C, PTGS2 and PFG) showed an AUC value higher than 0.8 (0.802; 95\% CI, 0.707-0.897) (Table 2).

Table 2. ROC parameters for diagnosis of CCR patients with metastasis using serum biomarker combinations.

\begin{tabular}{ccccccc}
\hline & AUC & $\mathbf{9 5 \%}$ CI & PPV & NPV & Sensitivity (\%) & Specificity (\%) \\
\hline JAG1-GUCY2 & 0.819 & $0.728-0.910$ & 100 & 46 & 63.8 & 100 \\
JAG1-PTGS2 & 0.831 & $0.743-0.743$ & 100 & 47.4 & 66.1 & 100 \\
GUCY2-PTGS & 0.879 & $0.805-0.953$ & 100 & 57.6 & 75.9 & 100 \\
PFG-PTGS2 & 0.852 & $0.772-0.933$ & 100 & 51.4 & 70.5 & 100 \\
GUCY2-PFG- PTGS2 & 0.802 & $0.707-0.897$ & 100 & 45.2 & 60.3 & 100 \\
\hline
\end{tabular}

AUC, area under the curve; PPV, positive; NPV, negative predictive values.

\subsection{Correlation Analysis of Biomarkers, Treatment Response and Metastasis}

Analysis of biomarkers to determine their correlation with treatment response showed that only the expression of GUCY2C in patients' serum could correlate with therapeutic response using the antiangiogenic agent. In fact, $76.9 \%$ of patients with high serum GUCY2C expression had a better course of the disease while progression was observed in only $20 \%$ of patients with high GUCY2C expression ( $p=0.047)$. This significant result was also observed 
for the combination of GUCY2C-PTGS2 in the serum of patients treated with an antiangiogenic agent $(p=0.047)$. In addition, the serum of patients treated without antiangiogenic agents showed a low expression of GUCY2C-PGF, which was of statistical significance to predict treatment response $(p=0.043)$. Finally, we analyzed the association between biomarkers and the presence of metastasis. Our results demonstrated that patients with metastases in more than one organ have higher expression of PTGS2 in serum $(p=0.024)$. In addition, patients with exclusive liver metastasis, as well as those with metastasis in a single organ $(p=0.029)$, have higher expression of PGF in blood $(p=0.02)$.

\subsection{Biomarker Correlation with Overall Survival or Progression-Free Survival}

In our study population, overall survival rates were $95.3 \%$ at 6 months, $75 \%$ at 1 year and $31.2 \%$ at 3 years. The probabilities of progression-free survival at 6 months, 1 year and 3 years were $77.5 \%, 69.7 \%$ and $64.4 \%$, respectively (Figure S1). However, no biomarker was significant for overall survival or progression-free survival. In addition, our results were not significant for progression-free survival according to degree of differentiation. Only one significant relationship between overall survival and type of metastasis was observed. Concretely, patients with single-organ metastases had greater survival rates $(p=0.002)$ (Figure S1). For both death and disease progression, all biomarker combinations showed reasonable specificity values but low sensitivity. The most remarkable value was the high blood expression of JAG1 and PGF, with sensitivity and specificity values of $60 \%$ to predict disease progression.

\section{Discussion}

Early detection of metastatic CRC is essential for prompt initiation of treatment to improve patient prognosis. Unfortunately, no sensitive biomarkers have been determined to detect this stage of the disease. Therefore, research on novel markers for metastatic CRC is a priority. In this study we analyzed different markers known to be related to angiogenesis, an essential process for the development of the metastatic stage of CRC, in blood and serum to determine their diagnostic ability.

A large number of CRC biomarkers have been analyzed, including DNA, RNA, proteins, volatile organic compounds, metabolites and fecal bacteria, although their clinical application depends on the degree of invasiveness of the procedure. In this context, "liquid biopsy" is becoming an essential methodology for the development of new markers [45]. RNA in blood or serum has shown good diagnostic performance and high sensitivity to distinguish different stages of the disease. Recently, RT-qPCR and dPCR of MACC1 and S100A4 (metastasis-associated in colon cancer 1 and S100 calcium-binding protein A4, respectively) transcripts in serum have been correlated with diagnosis, progression-free survival and overall survival of ovarian cancer [46]. In CRC, qPCR of serum HMGA2 oncofetal protein mRNA correlated significantly with its presence in tumors and has been proposed as a novel diagnostic marker for this disease [47]. Previous studies demonstrated that serum SALL4 mRNA levels in CRC patients correlated significantly with the degree of tumor invasion and differentiation with high sensitivity and specificity $(96 \%$ and $95 \%$, respectively), according to ROC analysis [48]. Similarly, tetraspanin 8 membrane protein (TSPAN8) mRNA in whole blood of CRC patients also showed notable sensitivity (83.6\%) and specificity $(58.2 \%)(\mathrm{AUC}=0.751)$ to differentiate patients from healthy donors [49]. This protein, which promotes angiogenesis among other functions, has been recently proposed as a potential target for CRC radio-immunotherapy [50].

Given the complex map of genetic disturbances that may underlie angiogenic mechanisms, it appears necessary to use a wide and heterogeneous group of potential biomarkers, representative of the angiogenic process, key in metastasis and tumor progression. In this context, angiogenesis-related genes were used to analyze their discriminatory power to distinguish between patients with CRC and healthy donors. These genes showed better performance in serum than in blood. In fact, three genes associated with angiogenesis (JAG1, PTGS2 and GUCY2C) showed statistically significant differential expression in 
blood cells of CRC patients compared to controls. Interestingly, serum mRNA levels of JAG1, PTGS2 and GUCY2C showed greater differences between CRC patients and healthy controls than those detected in blood. Furthermore, a positive regulation of $P G F$ in the serum of CRC patients was detected (but not in blood). Our results support the hypothesis of the overactivation of angiogenesis in metastatic CRC disease through several positively regulated pro-angiogenic factors (Figure 5) that can be detected as circulating mRNA [51].

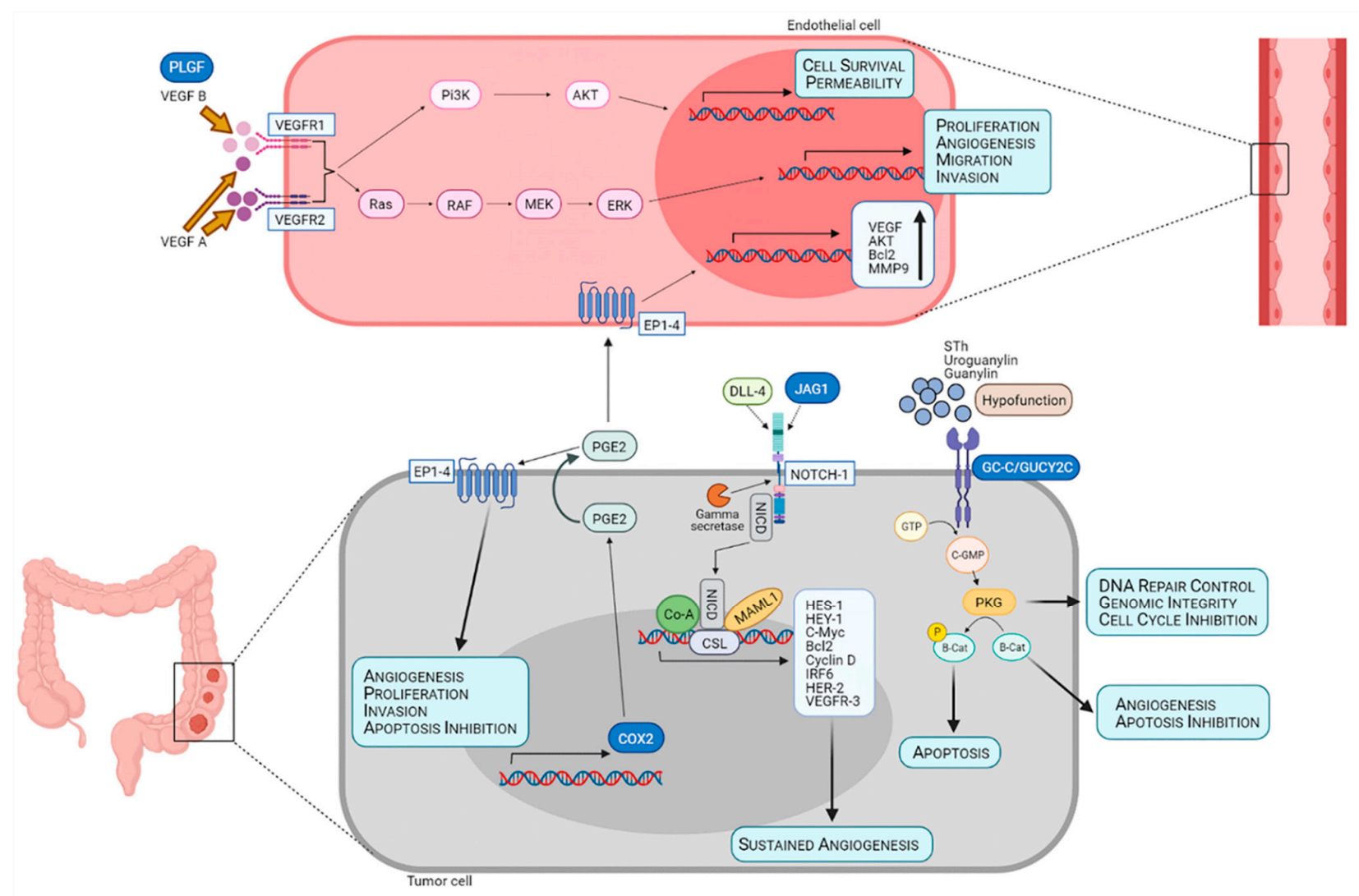

Figure 5. Schematic illustration summarizing the role of JAG1, PTGS2, GUCY2C and PLGF in tumor angiogenesis. PLGF (also termed PGF) may promote angiogenesis in vascular endothelial cells by binding to the VEGF receptor (VEGFR1), thereby increasing the availability of VEGF A for activation of VEGFR2, which exhibits higher kinase activity to induce angiogenesis-promoting signaling and other processes that favor tumor growth. The Notch pathway is activated through the binding of JAG1, among other ligands, to the receptor on the tumor cell surface, releasing the intracellular domain from the membrane that translocates to the nucleus, where it forms a complex to induce the transcription of several target genes that favor sustained angiogenesis. Transcription of PTGS2 (also termed COX2) mediates the production of prostaglandin E2 (PGE2) by tumor cells, which may act in a paracrine way by binding to prostaglandin receptors (EP1, EP2, EP3 or EP4) on the endothelial cell and inducing proliferation and angiogenesis, or in an autocrine way to further support angiogenesis and tumor promotion. In colon cancer, the tumor-suppressor gene GUCY2C (also referred to as GC-C) is upregulated but maintained in a hypoactivated state due to a lack of ligands, resulting in impaired signaling and leading to loss of genomic integrity, apoptosis inhibition and angiogenesis.

Analysis of the predictive ability of our selected biomarkers suggested that these proangiogenic factors could be clinically relevant in metastatic CRC. Although the presence of JAG1 in blood showed some discriminatory capacity (AUC of 0.858), the best performance was obtained with the use of serum samples in which PTGS2, GUCY2C and JAG1 showed remarkable values, particularly PTGS2 (AUC of 0.984 (0.963-1.000)) and GUCY2C (AUC of 0.896 (0.803-0.988)). To our knowledge, PTGS2 was detected in CRC tumor tissue and correlated with increased mortality [52]. In fact, recently, PTGS2 overexpression in tumor tissues of CRC patients (immunohistochemical and qPCR method) was closely associated with clinico-pathological data demonstrating a more pronounced expression in males 
vs. females [53]. On the other hand, in a large prospective multicenter blinded study conducted by Waldman et al. (2009) [54] that included 257 patients, GUCY2C mRNA allowed for the detection of metastases in patients considered stage II. Recently, GUCY2C mRNA expression profiling in tissue helped to stage CRC primary tumors and detect occult metastases [55]. In addition, JAG1 mRNA was the only biomarker that displayed similar notable results in both blood (AUC of 0.858) and serum (AUC of 0.840) samples from CRC patients. This interesting marker, which was already known to be closely related to vasculogenesis regulation, exerts pro-oncogenic functions [56]. In fact, anti-JAG1 antibodies have been proposed as an advanced therapy for cancer patients with high JAG1 tissue expression [57]. In a cohort of 158 CRC patients and using immunohistochemical detection, Sugiyama et al. (2016) [41] demonstrated that high JAG1 expression levels were associated with poor prognosis through promotion of epithelial-to-mesenchymal transition and cell proliferation. Moreover, JAG1 mRNA expression was analyzed in tumor tissues from 20 patients with squamous cell carcinoma (SCC), showing that increased JAG1 transcription significantly correlated with poor overall survival [58].

The possibility of combining mRNA biomarkers to improve their CRC diagnostic performance has been extensively tested. In fact, seven mRNAs (annexin A3, C-type lectin domain family 4 (member D), lamin B1, proline rich gla, tumor necrosis factor, vanin 1 and interleukin 2 receptor beta) and three mRNAs (TSPAN8, lectin galactoside-binding soluble 4 and collagen type I alpha 2 chain) in blood were used by Rodia et al. (2016) and Marshall et al. (2010) [49,59], respectively, to detect CRC patients. In the latter study, the biomarker panel showed a specificity/sensitivity of $67.16 \% / 92.54 \%$. Interestingly, the recent inclusion of a new gene (antigen-related cell-adhesion molecule 6, CEACAM) in this biomarker panel improved performance, obtaining an AUC of 0.88 (sensitivity, 75\%; specificity, $87 \%$ ) in normal and high-risk/CRC subjects, and an AUC of 0.91 (sensitivity, 79\%; specificity, 94\%) in normal and low-risk/CCR subjects [60]. Surprisingly, the different combinations of our biomarkers in both serum and blood did not provide additional benefits. The lack of correlation between each individual biomarker in serum and blood cells in our study population supports the idea that whole blood and serum can be considered independent measurement sources. Furthermore, the negative result of combining biomarkers to improve their predictive value supports the recent idea of configuring panels consisting of uncorrelated biomarkers to reveal maximum information about patients [61].

Finally, the study of the relationship between biomarkers and clinical parameters in patients with CRC showed that only JAG1-PGF in blood reached significant values to predict disease progression. Some in vitro analyses showed that $J A G 1$ silencing reduced the invasiveness of CRC cells, their growth rate and the expression of some metastasis markers such as MMP-2 and MMP-9 [62]. In contrast, in vivo studies showed that high JAG1 expression correlated with poor survival in CRC patients [63]. Moreover, increased copy numbers of the Notch gene (Jagged-1 ligand) were a negative prognostic factor for survival and were associated with poor prognosis after CRC surgery [41]. Regarding the prediction of treatment response, the expression of the GUCY2C gene in serum was the best marker, being useful in predicting patient response both in those treated with antiangiogenic and without antiangiogenic agents. This approach has also been studied in a prospective analysis of first-line therapy with antiangiogenics by Giampieri et al. (2020) [51], who proposed early increase in circulating FGF-2 levels as a biomarker for patients most likely to benefit from this treatment [51]. Previously, also in metastatic colon cancer, increased serum levels of sTRAIL (serum-soluble TNF-related apoptosis-inducing ligand) were proposed as a useful biomarker for early evaluation of patients treated with antiangiogenic agents [64]. Finally, we only observed longer survival in metastatic patients when metastasis was present in a single organ, in accordance with previously studies reporting that patients with a single metastatic site had better prognosis for both cancer-specific survival and overall survival than patients with involvement of multiple organs [65]. 


\section{Conclusions}

In summary, we analyzed blood and serum samples to detect mRNA of genes involved in the angiogenic process with the aim of finding new biomarkers that may improve the diagnosis and prognosis of metastatic CRC patients. A prospective analysis of peripheral blood samples from 59 metastatic CRC patients showed that dPCR detection of PTGS2, GUCY2C and JAG1 upregulation in serum correlated with high discrimination ability. The highest discrimination performance was obtained with the use of PTGS2 mRNA (AUC of 0.984 ). In contrast, all biomarker combinations did not significantly improve this discriminatory ability. Interestingly, GUCY2C and GUCY2C/PTGS2 serum expression significantly correlated with therapeutic response. However, none of the biomarkers correlated with overall survival or progression-free survival. Although further studies, including studies on non-metastasic and chronic inflammation patients, will be necessary to elucidate their role, these findings suggest that angiogenesis-related genes can be used as potential non-invasive biomarkers for the diagnosis and/or prognosis of patients with metastatic CRC.

Supplementary Materials: The following are available online at https:/ /www.mdpi.com/article/10 $.3390 / \mathrm{jcm} 10112248 / \mathrm{s} 1$, Figure S1: Survival of metastatic CRC patients.

Author Contributions: Conceptualization, J.P., C.M., O.C. and C.J.-L.; methodology, C.J.-L., E.G.-F. and R.O.; software, A.A.-R. and M.E.-R.; validation, L.J.M.-G. and A.A.-R.; formal analysis, R.O. and M.E.-R.; investigation, C.J.-L., E.G.-F. and L.J.M.-G.; resources, C.J.-L. and E.G.-F.; data curation, R.O.; writing — original draft preparation, C.J.-L. and E.G.-F.; writing—review and editing, J.P., C.M. and O.C.; visualization, J.P., C.M. and O.C.; supervision, J.P., C.M. and O.C.; funding acquisition, J.P. All authors have read and agreed to the published version of the manuscript.

Funding: This work was partially supported by a grant from the Instituto de Salud Carlos III (ISCIII) (Project PI19/01478) (FEDER) and by the CTS-107 Group.

Institutional Review Board Statement: The study was conducted according to the guidelines of the Declaration of Helsinki and approved by Biomedical Research Ethics Committee of the Andalusian Public Health System in Granada (protocol code PI19/01478; No. 2020522131049; 29 July 2020).

Informed Consent Statement: Informed consent was obtained from all subjects involved in the study. Data Availability Statement: Not applicable.

Acknowledgments: The authors would like to thank technical assistance from the Centro de Instrumentación Científica (CIC) (University of Granada).

Conflicts of Interest: The authors declare no conflict of interest.

\section{References}

1. Bray, F.; Ferlay, J.; Soerjomataram, I.; Siegel, R.L.; Torre, L.A.; Jemal, A. Global cancer statistics 2018: GLOBOCAN estimates of incidence and mortality worldwide for 36 cancers in 185 countries. CA Cancer J. Clin. 2018, 68, 394-424. [CrossRef] [PubMed]

2. Guren, M.G. The global challenge of colorectal cancer. Lancet Gastroenterol. Hepatol. 2019, 4, 894-895. [CrossRef]

3. Smeets, D.; Miller, I.S.; O'Connor, D.P.; Das, S.; Moran, B.; Boeckx, B.; Gaiser, T.; Betge, J.; Barat, A.; Klinger, R.; et al. Copy number load predicts outcome of metastatic colorectal cancer patients receiving bevacizumab combination therapy. Nat. Commun. 2018, 9 , 4112. [CrossRef] [PubMed]

4. Afrasanie, V.A.; Marinca, M.V.; Alexa-Stratulat, T.; Gafton, B.; Paduraru, M.; Adavidoaiei, A.M.; Miron, L.; Rusu, C. KRAS, NRAS, $B R A F, H E R 2$ and microsatellite instability in metastatic colorectal cancer-Practical implications for the clinician. Radiol. Oncol. 2019, 53, 265-274. [CrossRef]

5. Morano, F.; Sclafani, F. Duration of first-line treatment for metastatic colorectal cancer: Translating the available evidence into general recommendations for routine practice. Crit. Rev. Oncol. Hematol. 2018, 131, 53-65. [CrossRef]

6. Fernandez Montes, A.; Martinez Lago, N.; Rua, M.C.; Gomez, J.D.L.C.; Villaroel, P.G.; Mendez, J.C.M.; Fernandez, M.J.; Fernandez, M.S.; Lopez, M.R.; Aldana, G.Q.; et al. Efficacy and safety of FOLFIRI/aflibercept in second-line treatment of metastatic colorectal cancer in a real-world population: Prognostic and predictive markers. Cancer Med. 2019, 8, 882-889. [CrossRef]

7. Van Cutsem, E.; Cervantes, A.; Adam, R.; Sobrero, A.; Van Krieken, J.H.; Aderka, D.; Aranda Aguilar, E.; Bardelli, A.; Benson, A.; Bodoky, G.; et al. ESMO consensus guidelines for the management of patients with metastatic colorectal cancer. Ann. Oncol. 2016, 27, 1386-1422. [CrossRef] 
8. Yoshino, T.; Arnold, D.; Taniguchi, H.; Pentheroudakis, G.; Yamazaki, K.; Xu, R.H.; Kim, T.W.; Ismail, F.; Tan, I.B.; Yeh, K.H.; et al. Pan-Asian adapted ESMO consensus guidelines for the management of patients with metastatic colorectal cancer: A JSMO-ESMO initiative endorsed by CSCO, KACO, MOS, SSO and TOS. Ann. Oncol. 2018, 29, 44-70. [CrossRef]

9. Jamal-Hanjani, M.; Quezada, S.A.; Larkin, J.; Swanton, C. Translational implications of tumor heterogeneity. Clin. Cancer Res. 2015, 21, 1258-1266. [CrossRef]

10. Ma, J.; Lin, Y.; Zhan, M.; Mann, D.L.; Stass, S.A.; Jiang, F. Differential miRNA expressions in peripheral blood mononuclear cells for diagnosis of lung cancer. Lab. Investig. 2015, 95, 1197-1206. [CrossRef]

11. Quandt, D.; Dieter Zucht, H.; Amann, A.; Wulf-Goldenberg, A.; Borrebaeck, C.; Cannarile, M.; Lambrechts, D.; Oberacher, H.; Garrett, J.; Nayak, T.; et al. Implementing liquid biopsies into clinical decision making for cancer immunotherapy. Oncotarget 2017, 8, 48507-48520. [CrossRef] [PubMed]

12. Cheung, A.H.; Chow, C.; To, K.F. Latest development of liquid biopsy. J. Thorac. Dis. 2018, 10, S1645-S1651. [CrossRef] [PubMed]

13. Bedin, C.; Enzo, M.V.; Del Bianco, P.; Pucciarelli, S.; Nitti, D.; Agostini, M. Diagnostic and prognostic role of cell-free DNA testing for colorectal cancer patients. Int. J. Cancer 2017, 140, 1888-1898. [CrossRef] [PubMed]

14. Cohen, J.D.; Li, L.; Wang, Y.; Thoburn, C.; Afsari, B.; Danilova, L.; Douville, C.; Javed, A.A.; Wong, F.; Mattox, A.; et al. Detection and localization of surgically resectable cancers with a multi-analyte blood test. Science 2018, 359, 926-930. [CrossRef]

15. Phallen, J.; Sausen, M.; Adleff, V.; Leal, A.; Hruban, C.; White, J.; Anagnostou, V.; Fiksel, J.; Cristiano, S.; Papp, E.; et al. Direct detection of early-stage cancers using circulating tumor DNA. Sci. Transl. Med. 2017, 9, 2415. [CrossRef]

16. Scholer, L.V.; Reinert, T.; Orntoft, M.W.; Kassentoft, C.G.; Arnadottir, S.S.; Vang, S.; Nordentoft, I.; Knudsen, M.; Lamy, P.; Andreasen, D.; et al. Clinical Implications of Monitoring Circulating Tumor DNA in Patients with Colorectal Cancer. Clin. Cancer Res. 2017, 23, 5437-5445. [CrossRef]

17. Maierthaler, M.; Benner, A.; Hoffmeister, M.; Surowy, H.; Jansen, L.; Knebel, P.; Chang-Claude, J.; Brenner, H.; Burwinkel, B. Plasma miR-122 and miR-200 family are prognostic markers in colorectal cancer. Int. J. Cancer 2017, 140, 176-187. [CrossRef]

18. Barault, L.; Amatu, A.; Siravegna, G.; Ponzetti, A.; Moran, S.; Cassingena, A.; Mussolin, B.; Falcomata, C.; Binder, A.M.; Cristiano, C.; et al. Discovery of methylated circulating DNA biomarkers for comprehensive non-invasive monitoring of treatment response in metastatic colorectal cancer. Gut 2018, 67, 1995-2005. [CrossRef]

19. Tsukamoto, M.; Iinuma, H.; Yagi, T.; Matsuda, K.; Hashiguchi, Y. Circulating Exosomal MicroRNA-21 as a Biomarker in Each Tumor Stage of Colorectal Cancer. Oncology 2017, 92, 360-370. [CrossRef]

20. Galamb, O.; Bartak, B.K.; Kalmar, A.; Nagy, Z.B.; Szigeti, K.A.; Tulassay, Z.; Igaz, P.; Molnar, B. Diagnostic and prognostic potential of tissue and circulating long non-coding RNAs in colorectal tumors. World J. Gastroenterol. 2019, 25, 5026-5048. [CrossRef]

21. Antoniotti, C.; Pietrantonio, F.; Corallo, S.; Braud, F.D.; Falcone, A.; Cremolini, C. Circulating Tumor DNA Analysis in Colorectal Cancer: From Dream to Reality. JCO Precis. Oncol. 2019, 3, 1-14. [CrossRef]

22. Mody, K.; Baldeo, C.; Bekaii-Saab, T. Antiangiogenic Therapy in Colorectal Cancer. Cancer J. 2018, 24, 165-170. [CrossRef] [PubMed]

23. Liu, W.; Zhang, J.; Yao, X.; Jiang, C.; Ni, P.; Cheng, L.; Liu, J.; Ni, S.; Chen, Q.; Li, Q.; et al. Bevacizumab-enhanced antitumor effect of 5-fluorouracil via upregulation of thymidine phosphorylase through vascular endothelial growth factor A/vascular endothelial growth factor receptor 2-specificity protein 1 pathway. Cancer Sci. 2018, 109, 3294-3304. [CrossRef] [PubMed]

24. Ilic, I.; Jankovic, S.; Ilic, M. Bevacizumab Combined with Chemotherapy Improves Survival for Patients with Metastatic Colorectal Cancer: Evidence from Meta Analysis. PLoS ONE 2016, 11, e0161912. [CrossRef]

25. Pinto, C.; Antonuzzo, L.; Porcu, L.; Aprile, G.; Maiello, E.; Masi, G.; Petrelli, F.; Scartozzi, M.; Torri, V.; Barni, S. Efficacy and Safety of Bevacizumab Combined With Fluoropyrimidine Monotherapy for Unfit or Older Patients With Metastatic Colorectal Cancer: A Systematic Review and Meta-Analysis. Clin. Colorectal Cancer 2017, 16, e61-e72. [CrossRef]

26. Hopirtean, C.; Nagy, V. Optimizing the use of anti VEGF targeted therapies in patients with metastatic colorectal cancer: Review of literature. Clujul Med. 2018, 91, 12-17. [CrossRef]

27. Hsu, H.C.; Lapke, N.; Chen, S.J.; Lu, Y.J.; Jhou, R.S.; Yeh, C.Y.; Tsai, W.S.; Hung, H.Y.; Hsieh, J.C.; Yang, T.S.; et al. PTPRT and PTPRD deleterious mutations and deletion predict bevacizumab resistance in metastatic colorectal cancer patients. Cancers 2018, 10, 314. [CrossRef]

28. Itatani, Y.; Kawada, K.; Yamamoto, T.; Sakai, Y. Resistance to Anti-Angiogenic Therapy in Cancer-Alterations to Anti-VEGF Pathway. Int. J. Mol. Sci. 2018, 19, 1232. [CrossRef]

29. Angelucci, A.; Delle Monache, S.; Cortellini, A.; Di Padova, M.; Ficorella, C. "Vessels in the Storm": Searching for Prognostic and Predictive Angiogenic Factors in Colorectal Cancer. Int. J. Mol. Sci. 2018, 19, 299. [CrossRef]

30. Ding, C.; Luo, J.; Fan, X.; Li, L.; Li, S.; Wen, K.; Feng, J.; Wu, G. Elevated Gab2 induces tumor growth and angiogenesis in colorectal cancer through upregulating VEGF levels. J. Exp. Clin. Cancer Res. 2017, 36, 56. [CrossRef]

31. Nixon, A.B.; Sibley, A.; Hatch, A.J.; Liu, Y.; Jiang, C.; Mulkey, F.; Starr, M.D.; Brady, J.C.; Niedzwiecki, D.; Innocenti, F.; et al Blood-based biomarkers in patients (pts) with metastatic colorectal cancer (mCRC) treated with FOLFOX or FOLFIRI plus bevacizumab (Bev), cetuximab (Cetux), or Bev plus Cetux: Results from CALGB 80405 (Alliance). J. Clin. Oncol. 2016, $34,3597$. [CrossRef]

32. Weickhardt, A.J.; Williams, D.S.; Lee, C.K.; Chionh, F.; Simes, J.; Murone, C.; Wilson, K.; Parry, M.M.; Asadi, K.; Scott, A.M.; et al. Vascular endothelial growth factor D expression is a potential biomarker of bevacizumab benefit in colorectal cancer. Br. J. Cancer 2015, 113, 37-45. [CrossRef] [PubMed] 
33. Maida, M.; Macaluso, F.S.; Ianiro, G.; Mangiola, F.; Sinagra, E.; Hold, G.; Maida, C.; Cammarota, G.; Gasbarrini, A.; Scarpulla, G. Screening of colorectal cancer: Present and future. Expert Rev. Anticancer Ther. 2017, 17, 1131-1146. [CrossRef] [PubMed]

34. Akil, A.; Gutierrez-Garcia, A.K.; Guenter, R.; Rose, J.B.; Beck, A.W.; Chen, H.; Ren, B. Notch signaling in vascular endothelial cells, angiogenesis, and tumor progression: An update and prospective. Front. Cell Dev. Biol. 2021, 9, 642352. [CrossRef]

35. Carrithers, S.L.; Barber, M.T.; Biswas, S.; Parkinson, S.J.; Park, P.K.; Goldstein, S.D.; Waldman, S.A. Guanylyl cyclase C is a selective marker for metastatic colorectal tumors in human extraintestinal tissues. Proc. Natl. Acad. Sci. USA 1996, 93, 14827-14832. [CrossRef]

36. Li, P.; Schulz, S.; Bombonati, A.; Palazzo, J.P.; Hyslop, T.M.; Xu, Y.; Baran, A.A.; Siracusa, L.D.; Pitari, G.M.; Waldman, S.A. Guanylyl cyclase $\mathrm{C}$ suppresses intestinal tumorigenesis by restricting proliferation and maintaining genomic integrity. Gastroenterology 2007, 133, 599-607. [CrossRef]

37. Liu, B.; Qu, L.; Yan, S. Cyclooxygenase-2 promotes tumor growth and suppresses tumor immunity. Cancer Cell Int. 2015, 15, 106. [CrossRef]

38. Wu, Q.B.; Sun, G.P. Expression of COX-2 and HER-2 in colorectal cancer and their correlation. World J. Gastroenterol. 2015, 21, 6206-6214. [CrossRef]

39. Haibe, Y.; Kreidieh, M.; El Hajj, H.; Khalifeh, I.; Mukherji, D.; Temraz, S.; Shamseddine, A. Resistance Mechanisms to Antiangiogenic Therapies in Cancer. Front. Oncol. 2020, 10, 221. [CrossRef]

40. Gacche, R.N. Compensatory angiogenesis and tumor refractoriness. Oncogenesis 2015, 4, e153. [CrossRef]

41. Sugiyama, M.; Oki, E.; Nakaji, Y.; Tsutsumi, S.; Ono, N.; Nakanishi, R.; Nakashima, Y.; Sonoda, H.; Ohgaki, K.; Yamashita, N.; et al. High expression of the Notch ligand Jagged-1 is associated with poor prognosis after surgery for colorectal cancer. Cancer Sci. 2016, 107, 1705-1716. [CrossRef]

42. Xiu, M.X.; Liu, Y.M.; Kuang, B.H. The oncogenic role of Jagged1/Notch signaling in cancer. Biomed. Pharmacother. 2020, 129, 110416. [CrossRef] [PubMed]

43. Ii, M.; Yamamoto, H.; Adachi, Y.; Maruyama, Y.; Shinomura, Y. Role of matrix metalloproteinase-7 (matrilysin) in human cancer invasion, apoptosis, growth, and angiogenesis. Exp. Biol. Med. 2006, 231, 20-27. [CrossRef] [PubMed]

44. Maurel, J.; Nadal, C.; Garcia-Albeniz, X.; Gallego, R.; Carcereny, E.; Almendro, V.; Marmol, M.; Gallardo, E.; Auge, J.M.; Longaron, R.; et al. Serum matrix metalloproteinase 7 levels identifies poor prognosis advanced colorectal cancer patients. Int. J. Cancer 2007, 121, 1066-1071. [CrossRef]

45. Yamada, T.; Matsuda, A.; Koizumi, M.; Shinji, S.; Takahashi, G.; Iwai, T.; Takeda, K.; Ueda, K.; Yokoyama, Y.; Hara, K.; et al. Liquid biopsy for the management of patients with colorectal cancer. Digestion 2019, 99, 39-45. [CrossRef]

46. Link, T.; Kuhlmann, J.D.; Kobelt, D.; Herrmann, P.; Vassileva, Y.D.; Kramer, M.; Frank, K.; Gockenjan, M.; Wimberger, P.; Stein, U. Clinical relevance of circulating MACC1 and S100A4 transcripts for ovarian cancer. Mol. Oncol. 2019, 13, 1268-1279. [CrossRef] [PubMed]

47. Sahengbieke, S.; Wang, J.; Li, X.; Wang, Y.; Lai, M.; Wu, J. Circulating cell-free high mobility group AT-hook 2 mRNA as a detection marker in the serum of colorectal cancer patients. J. Clin. Lab. Anal. 2018, 32, e22332. [CrossRef]

48. Ardalan Khales, S.; Abbaszadegan, M.R.; Abdollahi, A.; Raeisossadati, R.; Tousi, M.F.; Forghanifard, M.M. SALL4 as a new biomarker for early colorectal cancers. J. Cancer Res. Clin. Oncol. 2015, 141, 229-235. [CrossRef]

49. Rodia, M.T.; Ugolini, G.; Mattei, G.; Montroni, I.; Zattoni, D.; Ghignone, F.; Veronese, G.; Marisi, G.; Lauriola, M.; Strippoli, P.; et al. Systematic large-scale meta-analysis identifies a panel of two mRNAs as blood biomarkers for colorectal cancer detection. Oncotarget 2016, 7, 30295-30306. [CrossRef] [PubMed]

50. Maisonial-Besset, A.; Witkowski, T.; Navarro-Teulon, I.; Berthier-Vergnes, O.; Fois, G.; Zhu, Y.; Besse, S.; Bawa, O.; Briat, A.; Quintana, M.; et al. Tetraspanin 8 (TSPAN 8) as a potential target for radio-immunotherapy of colorectal cancer. Oncotarget 2017, 8, 22034-22047. [CrossRef]

51. Giampieri, R.; Ziranu, P.; Daniele, B.; Zizzi, A.; Ferrari, D.; Lonardi, S.; Zaniboni, A.; Cavanna, L.; Rosati, G.; Casagrande, M.; et al. From CENTRAL to SENTRAL (SErum aNgiogenesis cenTRAL): Circulating predictive biomarkers to anti-VEGFR therapy. Cancers 2020, 12, 1330. [CrossRef] [PubMed]

52. Ogino, S.; Kirkner, G.J.; Nosho, K.; Irahara, N.; Kure, S.; Shima, K.; Hazra, A.; Chan, A.T.; Dehari, R.; Giovannucci, E.L.; et al. Cyclooxygenase-2 expression is an independent predictor of poor prognosis in colon cancer. Clin. Cancer Res. 2008, 14, 8221-8227. [CrossRef] [PubMed]

53. Negi, R.R.; Rana, S.V.; Gupta, V.; Gupta, R.; Chadha, V.D.; Prasad, K.K.; Dhawan, D.K. Over-Expression of Cyclooxygenase-2 in Colorectal Cancer Patients. Asian Pac. J. Cancer Prev. 2019, 20, 1675-1681. [CrossRef] [PubMed]

54. Waldman, S.A.; Hyslop, T.; Schulz, S.; Barkun, A.; Nielsen, K.; Haaf, J.; Bonaccorso, C.; Li, Y.; Weinberg, D.S. Association of GUCY2C expression in lymph nodes with time to recurrence and disease-free survival in pN0 colorectal cancer. JAMA 2009, 301, 745-752. [CrossRef] [PubMed]

55. Aka, A.A.; Rappaport, J.A.; Pattison, A.M.; Sato, T.; Snook, A.E.; Waldman, S.A. Guanylate cyclase C as a target for prevention, detection, and therapy in colorectal cancer. Expert Rev. Clin. Pharmacol. 2017, 10, 549-557. [CrossRef]

56. Li, D.; Masiero, M.; Banham, A.H.; Harris, A.L. The notch ligand JAGGED1 as a target for anti-tumor therapy. Front. Oncol. 2014, 4, 254. [CrossRef]

57. Lopez-Arribillaga, E.; Rodilla, V.; Espinosa, L. Could JAG1 protein inhibition prevent colorectal cancer? Future Oncol. 2019, 15, 345-347. [CrossRef] 
58. Chang, W.H.; Ho, B.C.; Hsiao, Y.J.; Chen, J.S.; Yeh, C.H.; Chen, H.Y.; Chang, G.C.; Su, K.Y.; Yu, S.L. JAG1 is associated with poor survival through inducing metastasis in lung cancer. PLOS ONE 2016, 11, e0150355. [CrossRef]

59. Marshall, K.W.; Mohr, S.; Khettabi, F.E.; Nossova, N.; Chao, S.; Bao, W.; Ma, J.; Li, X.J.; Liew, C.C. A blood-based biomarker panel for stratifying current risk for colorectal cancer. Int. J. Cancer 2010, 126, 1177-1186. [CrossRef]

60. Rodia, M.T.; Solmi, R.; Pasini, F.; Nardi, E.; Mattei, G.; Ugolini, G.; Ricciardiello, L.; Strippoli, P.; Miglio, R.; Lauriola, M. LGALS4, CEACAM6, TSPAN8, and COL1A2: Blood markers for colorectal cancer-validation in a cohort of subjects with positive fecal immunochemical test result. Clin. Colorectal Cancer 2018, 17, e217-e228. [CrossRef]

61. Kim, Y.S.; Kang, K.N.; Shin, Y.S.; Lee, J.E.; Jang, J.Y.; Kim, C.W. Diagnostic value of combining tumor and inflammatory biomarkers in detecting common cancers in Korea. Clin. Chim. Acta 2021, 516, 169-178. [CrossRef]

62. Dai, Y.; Wilson, G.; Huang, B.; Peng, M.; Teng, G.; Zhang, D.; Zhang, R.; Ebert, M.P.; Chen, J.; Wong, B.C.; et al. Silencing of Jagged1 inhibits cell growth and invasion in colorectal cancer. Cell Death Dis. 2014, 5, e1170. [CrossRef] [PubMed]

63. Arcaroli, J.J.; Tai, W.M.; McWilliams, R.; Bagby, S.; Blatchford, P.J.; Varella-Garcia, M.; Purkey, A.; Quackenbush, K.S.; Song, E.K.; Pitts, T.M.; et al. A NOTCH1 gene copy number gain is a prognostic indicator of worse survival and a predictive biomarker to a Notch1 targeting antibody in colorectal cancer. Int. J. Cancer 2016, 138, 195-205. [CrossRef] [PubMed]

64. Bisgin, A.; Kargi, A.; Yalcin, A.D.; Aydin, C.; Ekinci, D.; Savas, B.; Sanlioglu, S. Increased serum sTRAIL levels were correlated with survival in bevacizumab-treated metastatic colon cancer. BMC Cancer 2012, 12, 58. [CrossRef] [PubMed]

65. Luo, D.; Liu, Q.; Yu, W.; Ma, Y.; Zhu, J.; Lian, P.; Cai, S.; Li, Q.; Li, X. Prognostic value of distant metastasis sites and surgery in stage IV colorectal cancer: A population-based study. Int. J. Colorectal Dis. 2018, 33, 1241-1249. [CrossRef] 